\title{
Irrigation scheduling research: South African experiences and future prospects
}

\author{
JG Annandale ${ }^{1 *}$, RJ Stirzaker ${ }^{1,2}$, A Singels ${ }^{1,3}$, M van der Laan ${ }^{1,3}$ and MC Laker ${ }^{1}$ \\ ${ }^{1}$ Department of Plant Production and Soil Science, University of Pretoria, Private Bag X20, Hatfield, Pretoria 0028, South Africa \\ ${ }^{2}$ CSIRO Land and Water, PO Box 1666, ACT 2601, Australia \\ ${ }^{3}$ South African Sugarcane Research Institute, Private Bag X02, Mount Edgecombe 4300, South Africa
}

\begin{abstract}
Many scheduling approaches have been developed with Water Research Commission funding over the past 4 decades and deployed with varying levels of success; 2 approaches have won prestigious international awards. Soil-based approaches which include measurement of matric potential (tensiometry), water content (neutron probes, capacitance sensors) and depth of wetting (wetting front detectors) have been relatively well accepted by farmers. Atmospheric-based approaches apply, through biophysical modelling of the soil-crop-atmosphere system, thermodynamic limits to the amount of water that can evaporate from a cropped surface under particular environmental conditions. Modelling approaches have been quite empirical or somewhat more mechanistic, generic or crop specific, with pre-programmed (e.g. irrigation calendars) or real-time output. Novel mechanisms have been developed to deliver recommendations to farmers, including resource-poor irrigators. Although general adoption of objective irrigation scheduling in South Africa is still low, the high cost of electricity and nitrogen, and scarcity of water is reviving the interest of consultants and irrigators in the application of these tools to use water more efficiently. Where adoption has been relatively high, intensive support and farmer-researcher-consultant interactions have been key contributing factors. We propose 4 avenues in the R\&D domain to ensure responsible water utilisation. Firstly, there is a need to continue to advance existing soil-water measurement technology; and secondly, to further develop new and emerging technologies, like the use of remote sensing. Thirdly, the user-friendliness should be improved as should systems that support existing scheduling tools; and finally, we need to appreciate that farmers are intuitively adaptive managers, and we need to develop simple monitoring tools and conceptual frameworks that enable structured learning.
\end{abstract}

Keywords: BEWAB; CANESIM; PUTU; SWB; wetting front detector

\section{Introduction}

South Africa receives an average rainfall of $495 \mathrm{~mm}$, well below the global average of $860 \mathrm{~mm} / \mathrm{a}$. The total renewable water available per inhabitant is just $1106 \mathrm{~m}^{3} / \mathrm{a}$, placing South Africa among the driest quintile of countries in the world (FAO, 2005). According to international criteria, over $90 \%$ of South Africa is classified as dryland, i.e. arid to sub-humid, with $82 \%$ being classified as arid to semi-arid (ARC-ISCW, 2005). Most of the country receives summer rain that is poorly distributed, with droughts being common phenomena (Bennie and Hensley, 2001). Most of the sub-humid to humid areas are non-arable due to steep slopes and/or poor quality soils.

Thus, only around $13 \%$ (14 $\times 10^{6}$ ha) of the country is suitable for rain-fed cropping. Irrigation is practised on an estimated $1.5 \times 10^{6}$ ha and approximately $0.26 \times 10^{6}$ ha are affected by waterlogging and/or salinisation (FAO, 2005). A large proportion of irrigated land is in areas that are too dry for rain-fed cropping, and the area is limited mainly by water scarcity.

Irrigated agriculture is by far the biggest user of runoff water in South Africa. In 2000 irrigated agriculture used $7900 \times 10^{6} \mathrm{~m}^{3}$ of runoff, around $61 \%$ of the $12900 \times 10^{6} \mathrm{~m}^{3}$ runoff used by all sectors during that year or just under $40 \%$

This paper was originally presented at the Water Research

Commission 40-Year Celebration Conference, Kempton Park,

31 August - 1 September 2011.

* To whom all correspondence should be addressed.

of +27 12420 3223; fax: +27 124204120 ;

e-mail: john.annandale@up.ac.za of the estimated $20 \times 10^{9} \mathrm{~m}^{3}$ exploitable runoff (DWAF, 2004). Because of this large proportion of South Africa's blue water resources being used by irrigated agriculture, there is understandably a great deal of pressure to transfer water to other sectors. This could have major implications for food security, since a large proportion of several food crops is produced under irrigation, e.g. about $90 \%$ of all fruit and vegetables (Nieuwoudt et al., 2004). In view of the scarce water resources and the huge demand by irrigated agriculture, South Africa's Water Research Commission (WRC) has over its 40-year history continuously invested in developing tools that can assist water managers and growers to optimise irrigation water-use efficiency.

The primary aim of irrigation scheduling is to minimise wasteful losses of water (percolation beyond what is necessary for salt leaching, surface runoff and evaporation) and maximise transpiration, which is the beneficial loss of water due to its direct link with dry matter production (Tanner and Sinclair, 1983). Scheduling, therefore, plays a fundamental role in determining crop water productivity (CWP), which is a performance indicator used to describe the relationship between water applied and agricultural product output.

The pioneering work of, inter alia, Gardner (1960), Denmead and Shaw (1962) and Passioura (1988), set the fundamental theoretical framework of soil-plant-water relations. Much of the research over the past few decades has been to operationalise this framework, i.e. to make it useful to irrigation farmers. This has involved the characterisation of soil-water holding properties, the development of soil-water monitoring tools and methods to predict plant-water use. Although enormous progress has been made, and the scientific 
elements of the irrigation scheduling package appear to be in place, adoption by irrigators remains limited in South Africa and internationally (Leib et al., 2002; Stevens et al., 2005;

Stirzaker, 2006). A survey of 332 irrigation schemes in South Africa by Stevens et al. (2005) indicated that objective scheduling was being applied by $18 \%$ of farmers only, with the rest relying on approaches based on 'instinct, knowledge, experience and confidence gained over many years of farming'. In practice, irrigators often irrigated with fixed amounts or at a constant interval with little regard to variability in weather conditions and actual crop-water requirements.

The objective of this review is to document irrigation scheduling-related research over the past 4 decades in South Africa, with the main emphasis on the advances made through WRC-funded irrigation scheduling research and technologytransfer projects. The aim is to highlight technical achievements of soil- and atmospheric-based scheduling approaches, to reflect on why adoption of new technology has been much lower than expected, and to consider possible approaches needed to take irrigation scheduling forward in the future.

\section{An overview of WRC-funded irrigation scheduling and related research in South Africa}

During the late 1970s and early 80s, WRC-funded research focused on allowable depletion, or the so-called 'profile available water capacity' (PAWC) concept, and models to derive PAWC values for different crop-soil combinations. There was also research during this early period on irrigation scheduling of agronomic, vegetable and pasture crops. By the late 1980s, the focus had shifted to atmospheric-based soil-water balance modelling, with much of the results of this work put into practice by the late 1990s, with the development of a variety of computer-based scheduling approaches. The turn of the millennium saw the first of the social science research looking at technology adoption issues. Thereafter there was continued development of existing methods and their deployment in a variety of specific applications with greater focus on technology transfer. Lastly there was an attempt to develop irrigationscheduling tools for the small-scale irrigation sector.

Table 1 shows a list of final reports emanating from WRCsponsored research projects on irrigation scheduling published since the early 1980 s, chronologically representing efforts and focus areas over the years. Most of these reports can be accessed and downloaded free of charge from the WRC's website (www.wrc.org.za). While a comprehensive review of this vast body of research is beyond the scope of this article, selected research that has enhanced our knowledge and the approach of researchers to assist irrigators in devising more effective scheduling programmes is discussed below.

\section{The concept of plant-available water}

Knowing when to irrigate, i.e. the optimum stage in the drying cycle at which to apply water, and how much plant-available water the soil profile can hold, can assist an irrigator in improving irrigation water-use efficiency. For the determination of allowable depletion or 'PAWC', as it was defined by South African researchers, the correct determination of both the upper and lower limits is required (Bennie, 1995; Hensley and De Jager, 1982.)

Since the soil-water potential at 'field capacity' differs widely between soils, a single soil-water potential value cannot be used for all soils (Bennie, 1995; Hensley and De Jager, 1982; Ratliff et al., 1983). For the fine sandy soils at Vaalharts (about $8 \%$ to $10 \%$ clay and a sand fraction highly dominated by fine sand), 'field capacity' is, for example, at a soil-water potential of about $-5 \mathrm{kPa}$ and much of the plant-available water is held

\begin{tabular}{|l|l|l|l|}
\hline \multicolumn{3}{|c|}{ Table 1 } \\
Details of final reports of irrigation scheduling related research projects sponsored by the Water Research Commission \\
\hline Year & Report Title & Report No. & Reference \\
\hline 1982 & The Determination of the Profile Available Water Capacities of Soils & $\begin{array}{l}\text { Univ. Fort } \\
\text { Hare Report }\end{array}$ & $\begin{array}{l}\text { Hensley and De Jager } \\
\text { (1982) }\end{array}$ \\
\hline 1983 & $\begin{array}{l}\text { Water Use Efficiency of Irrigated Crops as Influenced by Varying } \\
\text { Cultivation Practices and Root Configurations }\end{array}$ & UOFS Report & Botha et al. (1983) \\
\hline 1985 & The Development of Profile Available Water Capacity Models & $98 / 1 / 85$ & Boedt and Laker (1985) \\
\hline 1987 & $\begin{array}{l}\text { Research on a Weather Service for Scheduling the Irrigation of Winter } \\
\text { Wheat in the OFS }\end{array}$ & $117 / 1 / 87$ & De Jager et al. (1987) \\
\hline 1987 & $\begin{array}{l}\text { Evapotranspiration and Water Use Studies in Wheat and Soybeans with } \\
\text { the Help of the Weighing Lysimeter Technique }\end{array}$ & H2/1/87 & Meyer et al. (1987) \\
\hline 1988 & $\begin{array}{l}\text { Water Balance Model for Irrigation Based on Soil Profile Water Supply } \\
\text { Rate }\end{array}$ & $144 / 1 / 88$ & Bennie et al. (1988) \\
\hline 1989 & $\begin{array}{l}\text { Research on Improving Irrigation Management based on Soil Water } \\
\text { Monitoring and Detailed Knowledge of Profile Available Water Capacities }\end{array}$ & $166 / 1 / 89$ & $\begin{array}{l}\text { Vanassche and Laker } \\
\text { (1989) }\end{array}$ \\
\hline 1989 & $\begin{array}{l}\text { Correction factors for evaporimeter coefficients used for scheduling irriga- } \\
\text { tion of wheat }\end{array}$ & $151 / 1 / 89$ & Van Zyl et al. (1989) \\
\hline 1990 & Drupbesproeiing by Tamaties (Drip Irrigation of Tomatoes) & $185 / 1 / 90$ & Fischer and Nel (1993) \\
\hline 1993 & Practical Scheduling of Irrigation in the Northern Transvaal & $152 / 1 / 93$ & Burgers and Kirk (1993) \\
\hline 1994 & Research on the Climatic Dependence of Evaporation Coefficients & $260 / 1 / 94$ & Van Zyl and De Jager (1994) \\
\hline 1994 & $\begin{array}{l}\text { Research on Maximising Irrigation Project Efficiency in Different Soil- } \\
\text { Climate-Irrigation Situations }\end{array}$ & $226 / 1 / 94$ & $\begin{array}{l}\text { Mottram and De Jager } \\
\text { (1994) }\end{array}$ \\
\hline 1994 & $\begin{array}{l}\text { Waterverbruik en Waterverbruiksdoeltreffendheid van Gematigde } \\
\text { Aanplante Weidings onder Bespoeiing (Water Use and Water Use } \\
\text { Efficiency of Temperate Planted Pastures under Irrigation) }\end{array}$ & $257 / 1 / 94$ & Steynberg et al. (1994) \\
\hline
\end{tabular}




\begin{tabular}{|c|c|c|c|}
\hline \multicolumn{4}{|c|}{ Table 1 (continued) } \\
\hline Year & Report Title & Report No. & Reference \\
\hline 1995 & Proceedings of the Southern African Irrigation Symposium, Durban, 1991 & TT 71/95 & $\begin{array}{l}\text { Water Research } \\
\text { Commission (1995) }\end{array}$ \\
\hline 1996 & $\begin{array}{l}\text { The Response of Citrus Seedlings to Soil Compaction And Variations In } \\
\text { Soil Water Potential In the Upper Range of Plant-Available-Water }\end{array}$ & $261 / 1 / 96$ & Mkhize et al. (1996) \\
\hline 1996 & $\begin{array}{l}\text { Die Fasilitering van Tegnologie Oordrag deur Verbeterde Besproeiings- } \\
\text { riglyne vir Groente en ' } n \text { Meganistiese Gewasmodelleringbenadering } \\
\text { (Facilitating Technology Transfer through Improved Irrigation Guidelines } \\
\text { of Vegetables and a Mechanistic Crop Modelling Approach) }\end{array}$ & $476 / 1 / 96$ & Annandale et al. (1996) \\
\hline 1997 & $\begin{array}{l}\text { Reaksie van Gewasse op Voorafgeprogrammeerde Tekortbesproeiing } \\
\text { (Reaction of Crops to Pre-Programmed Deficit Irrigation) }\end{array}$ & $423 / 1 / 97$ & Bennie et al. (1997) \\
\hline 1998 & $\begin{array}{l}\text { Use of Computer Models for Agricultural Water Management on Ecotope } \\
\text { Level }\end{array}$ & $102 / 98$ & Bennie et al. (1998) \\
\hline 1999 & $\begin{array}{l}\text { SAPWAT: A Computer Program for Establishing Irrigation Requirements } \\
\text { and Scheduling Strategies in South Africa }\end{array}$ & $624 / 1 / 99$ & Crosby and Crosby (1999) \\
\hline 1999 & $\begin{array}{l}\text { Facilitating Irrigation Scheduling by Means of the Soil Water Balance } \\
\text { model }\end{array}$ & $753 / 1 / 99$ & Annandale et al. (1999a) \\
\hline 2000 & $\begin{array}{l}\text { Factors Which Influence the Acceptability of Irrigation Scheduling with } \\
\text { Specific Reference to Scheduling Models }\end{array}$ & $893 / 1 / 00$ & Botha et al. (2000) \\
\hline 2000 & $\begin{array}{l}\text { An investigation of the Stem Steady State Heat Energy Balance Technique } \\
\text { in Determining Water Use by Trees }\end{array}$ & $348 / 1 / 00$ & Savage et al. (2000) \\
\hline 2000 & $\begin{array}{l}\text { Irrigation Requirements of Selected Crops under Small-Scale Production: } \\
\text { Linking On-Farm and On-Station Research }\end{array}$ & $689 / 1 / 00$ & Walker (2000) \\
\hline 2001 & $\begin{array}{l}\text { Research on a Computerised Weather Based Irrigation Water Management } \\
\text { System }\end{array}$ & $581 / 1 / 01$ & De Jager et al. (2001) \\
\hline 2002 & $\begin{array}{l}\text { The Development of an Integrated Information System for Irrigation Water } \\
\text { Management Using the WAS, SWB and RISKMAN Computer Models }\end{array}$ & $946 / 4 / 02$ & Benadé et al. (2002) \\
\hline 2002 & $\begin{array}{l}\text { Water Use and Water Use Efficiency of Fodder Crops under Irrigation: } \\
\text { Part } 1 \text { - Annual Subtropical Crops }\end{array}$ & $573 / 1 / 02$ & Marais et al. (2002) \\
\hline 2002 & $\begin{array}{l}\text { Two Dimensional Energy Interception and Water Balance Model for } \\
\text { Hedgerow Tree Crops }\end{array}$ & $945 / 1 / 02$ & Annandale et al. (2002a) \\
\hline 2003 & $\begin{array}{l}\text { Optimization of Irrigation Management in Mango Trees by Determination } \\
\text { of Water and Carbon Demands to Improve Water Use Efficiency and Fruit } \\
\text { Quality }\end{array}$ & $1136 / 1 / 03$ & Pavel et al. (2003) \\
\hline 2003 & $\begin{array}{l}\text { The Selection and Calibration of a Model for Irrigation Scheduling of } \\
\text { Deciduous Fruit Orchards }\end{array}$ & $892 / 1 / 03$ & Volschenk et al. (2003) \\
\hline 2003 & $\begin{array}{l}\text { Deficit Irrigation Studies to Improve Irrigation Scheduling in Deciduous } \\
\text { Fruit Orchards }\end{array}$ & $892 / 2 / 03$ & Beukes et al. (2003) \\
\hline 2004 & Building Capacity in Irrigation Management with Wetting Front Detectors & TT 230/04 & Stirzaker et al. (2004) \\
\hline 2005 & $\begin{array}{l}\text { Technology Transfer of the Soil Water Balance (SWB) Model as a User- } \\
\text { Friendly Irrigation Scheduling Tool }\end{array}$ & TT $251 / 05$ & Annandale et al. (2005) \\
\hline 2005 & $\begin{array}{l}\text { The Range, Distribution and Implementation of Irrigation Scheduling } \\
\text { Models and Methods in South Africa }\end{array}$ & $1137 / 1 / 05$ & Stevens et al. (2005) \\
\hline 2007 & $\begin{array}{l}\text { Predicting the Environmental Impact and Sustainability of Irrigation with } \\
\text { Coal Mine Water }\end{array}$ & $1149 / 1 / 07$ & Annandale et al. (2007) \\
\hline 2008 & $\begin{array}{l}\text { Real Time Irrigation Advice for Small-Scale Sugarcane Production Using } \\
\text { a Crop Model }\end{array}$ & $1576 / 1 / 08$ & Singels and Smith (2008) \\
\hline 2009 & $\begin{array}{l}\text { Increasing Water Use Efficiency of Irrigated Sugarcane by Means of } \\
\text { Specific Agronomic Practices }\end{array}$ & $1577 / 1 / 09$ & Olivier et al. (2009) \\
\hline 2010 & $\begin{array}{l}\text { Standards and Guidelines for Improved Efficiency of Irrigation Water Use } \\
\text { from Dam Wall Release to Root Zone Application: Guidelines }\end{array}$ & TT 466/10 & Reinders et al. (2010) \\
\hline 2010 & Wetting Front Detector Transfer of Technology & $\mathrm{K} 8 / 599 / 4$ & $\begin{array}{l}\text { Stevens and Stirzaker } \\
(2010)\end{array}$ \\
\hline 2010 & $\begin{array}{l}\text { Adapting the Wetting Front Detector to Small-Scale Furrow Irrigation and } \\
\text { Providing a Basis for the Interpretation of Salt and Nutrient Measurements } \\
\text { from the Water Sample }\end{array}$ & $1574 / 1 / 10$ & Stirzaker et al. (2010b) \\
\hline
\end{tabular}


at high soil-water potentials, causing these soils to have unexpectedly high PAWC values of more than $100 \mathrm{~mm} \cdot \mathrm{m}^{-1}$ for crops like maize and wheat, Thus, as in the USA and elsewhere, it was realised that in situ determined 'drained upper limits' (DUL) had to be used. Boedt and Laker (1985) and Bennie et al. (1988) carried out several DUL determinations from which they derived remarkably similar regression equations for estimating DUL from the silt plus clay contents of different depth intervals of a soil profile (Bennie, 1995).

Hensley and De Jager (1982) defined the lower limit of PAWC using plant parameters; a point Hensley termed 'first material stress' (FMS). This is not to be confused with the more commonly used international lower limit for plantavailable water (PAW) of permanent wilting point, a much lower soil-water content, typically at a matric potential of around -1.5 MPa. Based on earlier work in KwaZulu-Natal, Hensley used wilting of maize between 10:00 and 10:30 as a visual indicator of stress (Hensley and De Jager, 1982). This worked well under the climatic conditions prevailing at Fort Hare, but during periods of extreme evaporative demand (Class A pan readings of up to $\left.14 \mathrm{~mm} \cdot \mathrm{d}^{-1}\right)$ at Vaalharts, it could not be used. Under such conditions, maize wilted at 10:00 even on soils that were at field capacity (Boedt and Laker, 1985). Pre-dawn leaf-water potential, measured by means of a pressure chamber, was found to be a good indicator of FMS under normal conditions. Under conditions of extreme evaporative demand, however, its results also became very erratic (Boedt and Laker, 1985; Laker et al., 1987).

Using the results of Hensley and De Jager (1982), Laker (1982) developed a model by means of which PAWC could be estimated accurately for different soils, using very simple soil properties. Boedt and Laker (1985) followed this up with PAWC studies with maize, wheat, cotton and peas on an even wider range of soils in 3 different regions, i.e. at Fort Hare (Eastern Cape), Vaalharts (Northern Cape) and Loskop (Mpumalanga). All PAWC estimates were for plants at full canopy and full root-system development. Vanassche and Laker (1989) determined PAWC at various growth stages for wheat, durum wheat and maize. Bennie and his co-workers made use of these concepts in the development of the BEWAB irrigation model (Bennie, 1995; Bennie et al., 1988; Bennie et al., 1997).

A significant finding in the various PAWC studies was that field crops could extract water to great depths and that PAWC was larger than had been assumed previously, especially in the fine sandy soils of Vaalharts (Boedt and Laker, 1985). Consequently intervals between irrigations could be stretched and evaporation losses were less than with more frequent irrigations. Flood irrigation was used in the experiments, but Bennie and his co-workers developed strategies for using it under overhead systems as well (Bennie, 1995). Scheduling irrigation in this way increased irrigation water-use efficiency, without compromising crop yields, compared with controls that were irrigated at shorter intervals, maintaining higher levels of plant-available water in soils (Hensley and De Jager, 1982; Boedt and Laker, 1985; Vanassche and Laker, 1989). This was in line with the findings of similar studies in the USA at the same time (e.g. Buchheim and Ploss, 1977).

An additional innovation studied during the PAWC research by Vanassche and Laker (1989) was 'deficit highfrequency irrigation', an irrigation-scheduling approach that was pioneered in the USA (e.g. Miller, 1977; English and Nakamura, 1982). In this approach the water content of the soil is not allowed to drop below the point of first material stress, i.e. the crop is never stressed. With 'deficit' is meant that the entire soil profile soil is not filled to DUL during an irrigation event - after initially starting on a full profile. Reasons for improved irrigation water-use efficiencies were extraction of more water from the deep subsoil; and leaving room for effective use of rain water if a rainfall event occurred shortly (within a few days) after irrigation (this is not relevant to arid areas).

Vanassche and Laker (1989) studied different variations of this type of deficit irrigation with maize and wheat, e.g. irrigation is applied each time that $75 \%$ of PAWC has been extracted, i.e. leaving $25 \%$ of PAWC, but enough water is applied to replenish it up to only $75 \%$ of PAWC and not up to full DUL. This approach generally gave better irrigation water-use efficiencies than other approaches, as was also found in the USA.

Laker (1985) discussed how knowledge of PAWC could be used to reduce design peaks so that various irrigation systems and systems designed with smaller capacities (thus being less expensive) could cope with crop-water requirements during peak demand periods. He also indicated how this could be implemented under, for example, centre-pivot irrigation, where a soil profile cannot be filled with a single large irrigation event - as under flood irrigation. Starting with a dry profile, the soilwater content could be built up by 'over-irrigating' in the early part of the season to have a full profile at the start of the peak demand period. By means of 'deficit high frequency' irrigation the soil water would then be extracted gradually during the peak demand, to end with a profile at FMS at the end of the peak period. Bennie and his co-workers devised different variations of this suggested approach and had great success with it in practical irrigation scheduling of field crops (Bennie, 1995; Bennie et al., 1997).

It was also applied successfully to some horticultural crops, such as tomatoes (Fischer and Nel, 1990; Fischer, 1995), and at farm scale with grapevines (Nel, 1995b). The latter was introduced during a period of severe water restrictions. A computerised irrigation system was used. A 'start irrigation' level was set at a soil-water content halfway between the upper and lower limits of PAWC. A 'stop irrigation' level was at a deficit $30 \mathrm{~mm}$ below the upper limit. This left a reserve capacity of $30 \mathrm{~mm}$ for interception and effective storage of rainfall, 'a most important consideration when the effective use of available irrigation water is to be maximised' (Nel, 1995b).

It is important to keep in mind that in the case of leafy vegetables deficit irrigation usually leads to significant yield losses, as for example found by Van Averbeke and Netshithuthuni (2010) with Chinese cabbage in a WRC-sponsored study. The shallow root system and the fact that a high water supply is required for maximum leaf growth means that very frequent full irrigations are required for these crops, i.e. the water content of the soil must be kept close to DUL the whole time.

During the past decade or more 'regulated deficit irrigation' (RDI) and 'partial root zone drying' (PRD) approaches have been widely researched as deficit irrigation strategies aimed at increasing water-use efficiencies in areas with water scarcity (reviewed by e.g. Costa et al., 2007). These have also been implemented successfully in practice. RDI is a method of stressing a crop at a specific growth stage (or stages) to control excessive vegetative growth without affecting fruit yield (Grant, 2000; Costa et al., 2007), so as to improve water-use efficiency and/or crop quality. In PRD irrigation is applied to half the root zone, while the other half is allowed to dry (Grant, 2000; Costa et al., 2007). It is implemented by irrigating alternative inter-rows (e.g. in vineyards), whereupon the dry side is irrigated, and the previously irrigated side is allowed to dry. 
RDI and PRD are particularly effective practices for grapevines and various deciduous fruit crops (Grant, 2000; Costa et al., 2007). Water-use efficiency (WUE) increases of up to over $60 \%$ or $70 \%$ without harming crop yield or quality have been recorded in best-case scenarios (Costa et al., 2007). In South Africa the use of RDI in deciduous fruit crop irrigation has, inter alia, been studied by Beukes et al. (2003). PRD has recently been studied intensively at the ARC-Infruitec/ Nietvoorbij as potential strategy for irrigating wine grapes in South Africa. This has been reported in several publications, including those by Lategan and Howell (2010) and Myburgh (2011a).

RDI and PRD give variable results with evergreen fruit crops (Costa et al., 2007). Mangoes are interesting in the sense that deficit irrigation not only achieved higher WUE (Pavel and De Villiers, 2004), but also produced larger and better quality fruit than full irrigation (Spreer et al., 2007).

Additional studies with deficit irrigation strategies have been conducted on various other types of crops (Costa et al., 2007). Potatoes, for example, generally gave negative results, because of the shallow root system, but in a best-case scenario irrigation water use was increased by $60 \%$ without lowering yield. Various types of vegetables generally gave negative responses to deficit irrigation.

There appears to be great scope and an urgent need for more research on deficit irrigation strategies in South Africa, considering different approaches and studying a variety of important crops.

\section{Measuring techniques for irrigation scheduling}

In order to implement different irrigation-scheduling strategies efficiently, measurements need to be made. Types of measuring techniques can be broadly classified as plant, soil or atmospheric based.

\section{Plant-based techniques}

Several plant-based measuring techniques have been studied for their potential use in irrigation scheduling. The 'pistol' type infrared thermometer for measuring canopy temperature received much attention as a potential practical tool for irrigation scheduling, because of its apparent ease of use (Reginato, 1995), but determining water stress from canopy and air temperatures proved problematic because of the effects of extreme atmospheric conditions, e.g. situations of very low vapour saturation deficit (VSD). A rather more complex 'crop water stress index' (CWSI) taking VSD into account had to be developed to complement this device (Idso et al., 1981; Jackson et al., 1981).

Measurement of leaf-water potential has received by far the most attention of the plant-based measurement techniques in irrigation scheduling. Savage and his co-workers at the University of KwaZulu-Natal are internationally renowned for their studies on thermocouple psychrometers as method to determine leaf-water potential (e.g. Savage and Wiebe, 1987). However, Scholander-type pressure chambers have been most widely used for determining leaf-water potential, including in South Africa (e.g. Hensley and De Jager, 1982; Boedt and Laker 1985; Vanassche and Laker, 1989; Nel, 1995a). Although midday determination of leaf-water potential has been used successfully (e.g. Nel, 1995a), pre-dawn leaf-water potential under normal conditions gives the best indication of the onset of water stress in plants (Hensley and De Jager, 1982; Boedt and Laker, 1985, Vanassche and Laker, 1989; Laker, 2004) because shortly before dawn, leaf-water potential equilibrates with soil-water potential (Laker, 2004). The exception is under extremely hot, dry conditions, such as often experienced in summer in the central irrigation areas of South Africa, conditions under which pre-dawn leaf-water potential measurements were shown to be unreliable (Boedt and Laker, 1985; Laker et al., 1987; Vanassche and Laker, 1989). Similar problems have been found with other plant-based measurements also under extreme conditions (Reginato, 1995). Research using pre-dawn leaf-water potential by means of Scholander-type pressure chambers has produced threshold values that have facilitated its use in practical irrigation scheduling on a limited scale, for example in the wine-grape industry in the Western Cape. Some irrigation scheduling consultants provide advice using pressure chambers, and a few wine estates also operate their own instruments (Myburgh, 2011b). Many other plant-based measurements have been researched in South Africa (e.g. stomatal conductance, $\mathrm{CO}_{2}$ exchange rate, sap flow, leaf extension rate), but none of these have evolved into practical irrigation-scheduling methods.

\section{Soil-based techniques}

Measurement of soil-water status has a long history, from the tensiometers developed in the 1930s (Richards and Neal, 1936), to the neutron probe in the 1950s (Gardner and Kirkham, 1952), through to a whole range of tools based on the measurement of the dielectric properties of water in soil (Charlesworth, 2005). Perhaps the most familiar tool to irrigators is the tensiometer, which measures matric potential (suction) at the wet end of the plant-available water spectrum, making it valuable for horticultural crops. Streutker (1978) used tensiometers to keep the top $(0 \mathrm{~cm}$ to $45 \mathrm{~cm})$ soil layer at a high water potential and the subsoil water at a low water potential, achieved through medium frequency irrigation. This early research demonstrated how objective scheduling could result in significant water savings with no loss of yield.

Streutker et al. (1981) promoted the use of tensiometers in the Loskop Irrigation District during the 1980s, and was very successful at improving irrigation management by, amongst other interventions, highlighting the contribution of shallow water tables to crop-water use. They developed water-yield functions for several crops enabling farmers to benchmark their water productivities and gauge whether or not they had room to improve.

The neutron probe has long been the standard instrument for measuring soil-water content. It has been used with great success in practical irrigation management, especially in orchards and vineyards (Mkhize et al., 1996; Nel, 1995b). On a large commercial citrus estate near Marble Hall, Mkhize et al. (1996) were able to demonstrate $24 \%$ water saving, while increasing yield and fruit quality through neutron-probe scheduling following a PAWC approach, thereby facilitating a significant saving in irrigation costs. The neutron probe is, however, being superseded by a range of logged capacitancetype sensors, such as DFM capacitance probes (Haarhoff, 2011). Although potentially not as representative as neutron probes because of their smaller volume of measurement, automated capacitance sensors are usually far easier to deploy in farmers' fields.

The wetting front detector (WFD) was conceived and developed against the background of poor adoption of commonly available technologies. Essentially the WFD reframed the age-old irrigation scheduling question from "when to turn 
the water on' to 'when to turn it off' (Stirzaker, 2003). The focus of soil-based monitoring had been on specifying refill points, i.e. how dry the soil could be allowed to get without affecting production of the crop. Long intervals between irrigation events meant that sprinklers could be moved less often; however, the advent of micro-irrigation changed this perspective. Irrigation could occur at any time, and was often carried out daily or pulsed several times per day.

WFDs are based around the tipping-bucket analogy, where soil layers are viewed as a sequence of buckets that store water. As the upper bucket is filled by irrigation, it tips and spills excess water into the bucket below and so on down the profile. The WFD was designed to show when water moved from one layer to the next. It is comprised of a specially shaped funnel, a filter, and a float plus indicator mechanism. The funnel shape was designed so that the soil at its base reaches saturation when matric potential of the soil outside the funnel is around $2 \mathrm{kPa}$ to $3 \mathrm{kPa}$ (Stirzaker 2008), which corresponds to a relatively 'strong' wetting front. Once saturation occurs at the base of the funnel, free water flows through a filter into a small reservoir and activates a float. The float trips a magnetically latched indicator, visible to the irrigator. These detectors are often installed at different depths and used in a similar way to that for tensiometry, namely a shallow detector indicating water entering the root zone and a deeper detector possibly warning of over-irrigation (Stirzaker and Hutchinson 2005).

Fessehazion et al. (2011) used WFDs and the principles of adaptive management to manage excess nitrogen use in irrigated pastures. In this case, the depth of wetting and nitrate concentrations recorded in WFDs were measurements that broadly integrated many of the processes involved in the soilwater balance and $\mathrm{N}$ cycle. Even simple thresholds for action were able to reduce $\mathrm{N}$ application by up to one third, whilst retaining yield levels and improving the quality of the pasture in which this application was tested.

\section{Atmospheric-based approaches}

Atmospheric-based approaches apply, through biophysical modelling of the soil-crop-atmosphere system, thermodynamic limits to the amount of water that can evaporate from a cropped surface under a particular set of environmental conditions. Early work was based on evaporation measured from a pan together with crop coefficients which were then used to estimate evapotranspiration (ET) (Doorenbos and Pruitt, 1977). The standard Class A-evaporation pan was most widely used in South Africa, and was reported by Stevens et al. (2005) still to be popular amongst commercial farmers and consultants in the Breede Water Management Area. Customised approaches, such as the Scheepers and Vaalharts pan, have also been successfully used in the past, but only a limited number of Northern Cape farmers still use the Vaalharts pan to measure evaporation (Stevens et al., 2005). The aptly named 'Green Book' (Green, 1985) made extensive use of crop factors and evaporation pan data to estimate crop-water requirements of several crops throughout South Africa and was widely used, particularly for planning purposes.

The evaporation pan/crop coefficient approach was later shown to have serious limitations (Van Zyl et al., 1989). Panand crop-evaporation coefficients depend strongly on climate, and the use of constant values can lead to inaccurate estimates of crop evaporation (De Jager and Van Zyl, 1989; Van Zyl and De Jager, 1992; Annandale and Stockle, 1994). De Jager and Van Zyl (1989) proposed a breakdown of the single crop coefficient into vegetation and soil sub-components. Each of these was further broken down to account for canopy cover and plant- and soil-water status.

De Jager and Van Zyl (1989) used evaporation from a reference crop to represent atmospheric evaporative demand. This theoretical formulation of crop evaporation provided the basis for weather-based water-balance models used in many irrigation-scheduling tools and crop models.

Van Zyl and De Jager (1987) and Van Zyl et al. (1990) demonstrated the accuracy of the Penman-Monteith equation (the energy balance of a cropped surface), for estimating evaporation from an unstressed wheat crop and determined typical values of canopy conductance, a key plant parameter in this equation. Although the Penman-Monteith equation requires detailed weather data as input, Van Zyl and De Jager (1987) demonstrated that a modified method using sunshine duration, temperature and a Piché evaporimeter produced reliable evaporation estimates as well. This, and the development of automated weather stations, paved the way for the PenmanMonteith method to replace the evaporation pan/crop coefficient approach as a standard method to estimate crop-water use in South Africa at the time.

As automated weather stations became more common, the high-frequency measurement (every few seconds) of air temperature, vapour pressure deficit, wind speed and solar radiation, made the calculation of the evaporation from a reference crop surface based on energy balance principles, commonplace. The international community has settled on a standardised version of the Penman-Monteith equation, that assumes a full cover, well-watered, $12 \mathrm{~cm}$ tall reference crop, with an albedo of 0.23 and canopy resistance of $70 \mathrm{~s} \cdot \mathrm{m}^{-1}$ (Allen et al., 1998), and this has also been adopted in South Africa.

\section{Modelling the soil-water balance}

All approaches to modelling the soil-water balance have empirical and mechanistic aspects to them. Models are either crop-specific or can be described as 'generic' in nature if they can be used for several crops, with pre-programmed (e.g. irrigation calendars) or real-time output. Four WRC-supported irrigation-scheduling modelling efforts stand out. These are BEWAB, PUTU, SWB and MyCanesim.

Bennie et al. (1988) determined long-term average irrigation water requirements and efficient water-management strategies for various crops (wheat, maize, groundnuts, cotton and peas) for irrigation schemes in the semi-arid regions of South Africa (Vaalharts, Sandvet, Ramah). This new knowledge was incorporated into a software package named BEWAB (BEsproeiingsWAterBestuursprogram - Afrikaans for Irrigation Water Management Program) that was widely adopted by farmers. The package provided seasonal irrigation requirement and pre-plant schedules of irrigations for specific crop/site/soil/planting date scenarios. It also related irrigation requirements and schedules to a user-specified target yield through linear production functions derived from experimental data. Strydom (1998) incorporated transpiration efficiency concepts from Tanner and Sinclair (1983) into BEWAB, thus making it applicable to any site for which maximum biomass yield and maximum evapotranspiration information were available. The package suggested appropriate values for these inputs for different locations around South Africa.

The concepts developed by De Jager et al. (1987) were incorporated into the PUTU wheat model that was used to provide weekly irrigation scheduling advice to wheat farmers 
at Vaalharts. Electronically recorded weather data were downloaded via telephone modems and landlines. This was particularly impressive considering that these were manual telephone exchanges. The model was run by the research team to generate crop- and soil-water status information (e.g. expected onset of water stress, water use of the past 7 days, deep drainage out of the root zone, expected date of next irrigation and current soil-water status). This information was faxed to the local extension officer, who conveyed it to farmers when they phoned. This approach to advice dissemination was not very successful. The project highlighted the need for personal interaction with farmers and for marketing of the service to ensure better uptake.

The experience gained from this research also led to the development of a generic crop model (PUTU-anycrop) that was used to determine water and irrigation requirements of various crops (e.g. De Jager and Singels, 1994; De Jager et al., 2001). It was used by irrigation consultants and extension officers for weather-based irrigation scheduling at Bergville and Winterton in KwaZulu-Natal and on the Riet River and other Free State/Northern Cape irrigation schemes, as well as in Limpopo Province at ZZ2 on tomatoes and other crops (De Jager and Mottram, 1996; De Jager and Kennedy, 1996).

The SWB model is a mechanistic, generic crop model which was developed as a real-time irrigation-scheduling tool (Annandale et al., 1999a). Evapotranspiration is calculated according to the Penman-Monteith grass reference method as recommended by the Food and Agricultural Organization (FAO) (Allen et al., 1998). The soil-water balance can be modelled using either a cascading soil-water balance or a finite difference model (Annandale et al., 1999a). Daily crop dry matter accumulation was taken as the lower value of either radiation-limited growth (Monteith, 1977) or water-limited growth (Tanner and Sinclair, 1983). Thermal time was used to calculate phenology and partitioning with the effect of water stress accounted for through the use of a stress factor.

The crop- and soil-water components of the model have undergone extensive parameterisation and testing for commonly grown South African crops including potatoes, sunflower, maize, soybean, canola, fescue, lucerne and a wide range of vegetable crops (Jovanovic and Annandale 1999; Jovanovic et al., 1999; Annandale et al., 2000; Jovanovic and Annandale 2000a; Jovanovic et al., 2000b; Jovanovic et al., 2002; Tesfamariam, 2004; Annandale et al., 2007). An FAOtype crop factor approach was also included in the model to include crops for which limited data were available and for tree crops which cannot be 'grown' using the simple crop model (Jovanovic and Annandale, 1999).

Singels and Smith (2009) developed and implemented a weather-based irrigation scheduling advice service for sugarcane growers. The MyCanesim system (Fig. 1, described by Singels, 2007) was automatically executed daily on behalf of subscribers and advice was made available through web downloads for extension staff and commercial farmers, or by cellular text messages for small-scale farmers.

More details on the 4 irrigation-scheduling models described briefly above can be found in the references given.

\section{Adoption}

The research projects described above produced many novel mechanisms that were successfully applied by the target endusers. Yet when the irrigation industry is viewed as a whole, the picture is not reassuring. Stevens et al. (2005) showed that

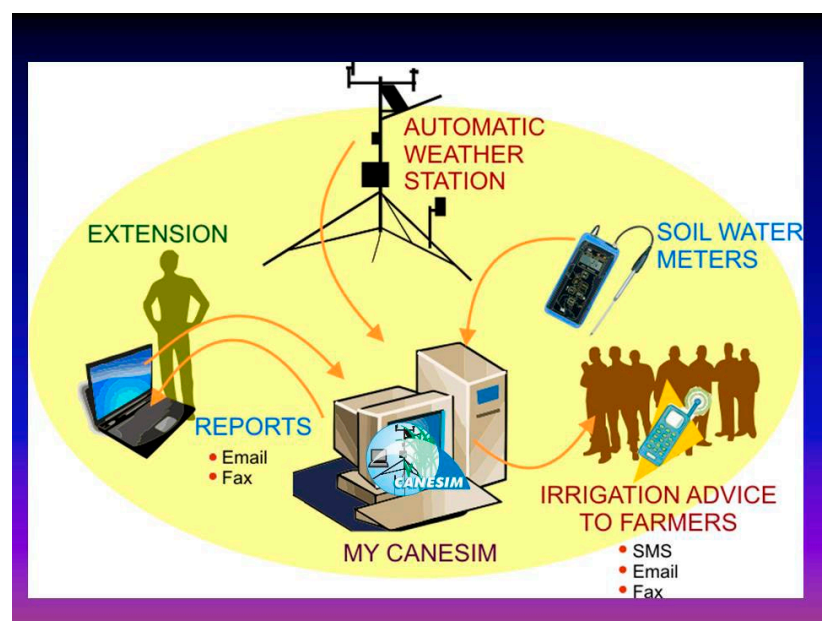

Figure 1

Schematic presentation of MyCanesim irrigation-scheduling system

only $18 \%$ of commercial irrigators used the products of science to help them schedule irrigation. Their national survey covered 332 irrigation schemes and included semi-structured interviews with irrigation professionals (consultants, advisors, industry experts and irrigation specialists), followed by a more quantitative survey of large- and small-scale farmers to better understand human factors influencing the adoption of objective scheduling.

Findings included that scheduling method was closely related to irrigation system, with users of mechanised systems (pivot, micro, drip) showing a positive view towards objective scheduling, and users of flood irrigation showing little interest. The technology level, size of the farm and value of crops grown were also found to influence adoption of more sophisticated scheduling methods. Flat-rate water tariffs on the majority of schemes provided little incentive to schedule objectively, while unreliable water delivery also hindered adoption. In many cases water was one of the cheapest inputs into the irrigation business, and so applying luxury quantities was considered a cheap form of insurance (Stirzaker, 1999). This could be an acceptable strategy in situations where over-irrigation is not considered problematic. However, in many situations injudicious over-irrigation can have serious negative impacts, such as, for example, raised water tables (often leading also to salinisation), high drainage costs, nutrient leaching, crop yield reductions and/or soil or human-health impacts.

In response to low adoption of the SWB model, the WRC commissioned a Technology Transfer project to train potential users at the national scale and to make software changes in order to improve user-friendliness. Annandale et al. (2005) reported that these training exercises were largely successful in general knowledge capacity building, but did not improve the adoption of the model itself. Many of the consultants were not irrigation advisors per se, but used the course to update and refresh their knowledge on plant/water relations. Others continued to use their own models or tools, and this was attributed to the fact that they were more familiar with their own systems and did not see enough benefit in changing over to another system. Some felt that the model was still too complex and required too many input parameters.

$\mathrm{BEWAB}$, on the other hand, was used by around 500 growers. Its successful adoption was ascribed largely to the credibility of the developer, Alan Bennie, who is a well-respected 
academic, but with the uncanny ability to translate basic scientific findings into practical solutions for on-farm management. He grew up on an irrigation farm at Vaalharts and is also a successful farmer in the area where it was rolled out. It is probable that the intimate knowledge of the local conditions, including knowledge of the views and attitudes of the local farmers, was instrumental in developing a product that satisfied the particular needs of those farmers

In many ways, PUTU was a technology developed ahead of its time. Considering rapid development in communication and computer infrastructure, it might have been more successful had it come 10 years later.

The development of MyCanesim was focused on the difficulties of getting buy-in from farmers. It was first implemented in 2004 on a small-scale grower scheme in Pongola (Singels and Smith, 2006), and in 2007, advice via text message was provided to 45 small-scale growers. Most of the farmers indicated that they found the advice useful and that it helped them to better understand the value of scheduling. Frequent face-to-face interaction with farmers was observed to be essential in ensuring that advice was understood and implemented. Reliable feedback on irrigation actions and rainfall was also needed to ensure accurate simulation and relevant advice. The approach followed was to provide direct, simple advice and not to confront users with the complexity of the system. This work received recognition by being awarded the International Commission on Irrigation and Drainage (ICID) WATSAVE Award for Innovative Water Management in 2007. Additional work is envisaged to further improve as well as implement this system more widely in the South African sugar industry.

The wetting front detector (WFD) was essentially pioneered in South Africa and the research and development effort was framed by the ongoing problem of poor adoption. After a minimum of 12 months' evaluation of prototype detectors, 54 irrigators, or their advisors who participated in the study, were surveyed. All participants perceived the device as simple and intuitive, and based on their own experience, $82 \%$ believed it conferred a relative advantage over what they had been doing (Stirzaker et al., 2010a). Those experiencing problems were either using furrow or centre-pivot irrigation, methods not ideally suited to the WFD.

In 2003, the team that developed the WFD were awarded the ICID WATSAVE award for 'outstanding contribution to water saving and water conservation in agriculture'. The following year the commercial version was released by a South African irrigation company. Over 15000 detectors were sold over the next 7 years, mostly in South Africa and Australia but also in Argentina, Chile, Peru, Spain and Greece. Yet the momentum of the early success has been difficult to maintain. Although a simple device, it turned out that a good deal of local knowledge was required to get the best out of the detectors. In particular, the depth of placement was crucial and the need to fit the soil type and irrigation method. Despite the sales volumes, the business model did not generate the returns that allowed advisors or consultants to learn and adapt and solve new problems as they arose. Successful adoption is far more than just the technology. The distribution network, back-up assistance and availability of spare parts are just as important.

Adoption of irrigation scheduling among the South African small-scale irrigation schemes has been particularly poor (Fanadzo et al., 2010). Water-limited crop productivity in small-scale irrigation schemes has been attributed to socio-economic, political, climatic, edaphic and design factors (Bembridge, 2000), and has been exacerbated by dilapidated irrigation equipment and poor farmer performance (e.g. poor weed and fertiliser management) (Crosby et al., 2000; Fanadzo et al., 2010). In such cases, it would be important to simultaneously address factors limiting primary production, whilst committing resources to irrigation-scheduling initiatives.

Poor adoption, therefore, remains a conundrum for those whose mandate it is to improve water-use efficiency. Eighteen years ago, Burgers and Kirk (1993) wrote '...computers are fast becoming an essential facility on farms, and a user-friendly program which computes the amount of water to be applied on each of the scheduled dates, may well be the answer to the farmer's scheduling problems'. This prediction has not materialised, and the use of computer models for irrigation scheduling, especially by farmers themselves, has remained low (Botha et al., 2000).

Similarly, it was expected that once soil-water monitoring equipment was more affordable and user-friendly, widespread adoption would follow naturally. Yet adoption seems to require a dedicated service as well. For example, the OrangeVaal Water Users Association, managed by Griqualand Wes Kooperasie (GWK), includes around 91000 ha of irrigated land (about 2600 centre-pivots) of which more than two-thirds is objectively scheduled, $55 \%$ to $65 \%$ by the GWK service, which makes use of 2 systems (Haarhoff, 2011). The older of the two is a simple neutron probe system on about 200 pivots, where farmers are sent weekly updates of soil-profile-water content via e-mail, fax or text message. The successful implementation of this system over many years is attributed to it being designed and customised around meeting the specific needs of farmers for the region (Crosby, 2004). The new technology used by GWK on about 1300 pivots uses DFM capacitance probes and Irricheck software that enables the farmer to make his own scheduling decisions. However, a service is still provided in that GWK offers support through field observations for probe calibration (Haarhoff, 2011).

Lower than expected adoption does not, in itself, question the value of the research effort. For example, SWB was originally conceived as a tool for farmers, but had more positive spin-offs in other applications. The model has been effectively used as a teaching tool in undergraduate courses on irrigation management (Jovanovic and Annandale, 2000b) and crop physiology (Jovanovic et al., 2000b). Many postgraduate students have also been involved with the inclusion of new routines into the model for specific research purposes. For example, the chemical equilibrium routine of Robbins (1991) has been included to enable salt simulations and was used to study the feasibility of irrigating crops with gypsiferous mine water (Annandale et al., 1999b; Annandale et al., 2001; Annandale et al., 2002b). Carbon, nitrogen and phosphorus subroutines have also been included to enable the investigation of nutrient dynamics for the determination of responsible municipal sludge application rates and nitrogen and phosphorus pollution at the field scale (Tesfamariam, 2009; Van der Laan, 2009; Van der Laan et al., 2010).

\section{Future focus and opportunities}

The emerging story of apparently successful research projects but only patchy adoption of its outputs by the industry remains the key challenge for the irrigation research community. Increases in population and wealth will only make the situation more urgent. On a global scale, it has been estimated that food production needs to double in the next 40 years (Godfray et al., 2010). This directly translates into a need for more irrigation water and more efficient irrigation practices. Already, 
water-balance studies in 2000 showed that 10 of the 19 water management areas investigated in South Africa could not meet demand (DWAF, 2004). In addition there remains much uncertainty on what the influence of changing weather patterns and elevated $\mathrm{CO}_{2}$ will be on crop-growth processes and water availability, but it is generally agreed that projected climate-change scenarios will lead to additional challenges to the irrigation industry.

Prior to 2008, the cost of electricity in South Africa was rated amongst the cheapest in the world (Jumman, 2009). Increases in population and fossil-fuel prices, coupled with infrastructure difficulties, has meant that the country's energy supplier has struggled to meet demand and electricity prices have escalated dramatically. Additional increases of $25 \%$ in 2011 and another $25 \%$ in 2012 have already been approved, and are expected to further impact negatively on the profitability of irrigation farming Various cost-saving options are now available to irrigators, for example the 'Nightsave' and 'Ruraflex' options, which are being introduced to encourage electricity use for irrigation during off-peak periods (Jumman, 2009).

We envisage 4 responses to the above challenges. First, continued advances in existing technology related to the direct measurement of volumetric soil-water content coupled with advances in remote data access through radio communication or via cellular networks, may still develop a cost-effective, real-time system of irrigation. This scenario invokes the concept of 'embodied technology' whereby the data collection and processing is done automatically, and the user receives a daily recommendation without having to understand how any of the technology actually works.

Second, new and emerging technology may yet overcome the barriers that have plagued existing technology. For example, space-borne remote sensing can be used to provide regular hydrological information for large areas and though used for research purposes in the past (Bastiaanssen et al., 2000), it is now receiving increased application in irrigationscheduling recommendations (e.g. Santos et al., 2008). Remote sensing is already being used in the Western Cape to assist table-grape and wine farmers to better manage scarce irrigation water resources and nitrogen fertiliser in a project sponsored by the Western Cape Department of Agriculture (see www.GrapeLook.co.za) (Posthumus, 2011). A second project using this technology in irrigated sugarcane production in the Mpumalanga Province, South Africa, has been launched and is co-funded by the WRC and the Department of Agriculture, Forestry and Fisheries. A third project is being planned for irrigated grain crops in the Middle-Orange River catchment (Van Vuuren, 2011). Such new and emerging technologies may, of course, also be very simple. For both highly sophisticated and simple technologies, proper field testing and validation under different environmental and socio-economic conditions should be a non-negotiable requirement.

Third, there are approaches that make 'user-friendliness' the main focus. The MyCanesim system described above is one such example. There has been a trend to provide real-time and pre-programmed irrigation scheduling advice via the internet [e.g. Wateright (California State University, USA); Citrus MicroSprinkler Irrigation Scheduler (University of Florida, USA); PlanteInfo (Denmark)]. Many of these systems allow the use of text-messaging technology to deliver the results. Car et al. (2010) investigated the feasibility of using a photograph, taken with a cell-phone and sent to an internet server via MMS technology, to calculate canopy cover and to estimate a crop coefficient $\left(K_{\mathrm{c}}\right)$.
A fourth approach is to use simple tools and engage irrigators in a process of adaptive learning by combining the best of different methods. For example, various strands of information, such as the experiential knowledge of the irrigator, the crop factor, depth of wetting, salt build-up and soil tension are combined to give a more complete picture of the irrigation dilemma (see for example http://thescientistsgarden.blogspot.com). This approach recognises that farmers are intuitively adaptive managers and the use of a robust conceptualisation combined with simple monitoring presents a way to structure their learning (Stirzaker, 2011).

Whichever approach we follow, biophysical scientists will need to remember the words of caution of their social science colleagues who have pointed out that technology-driven approaches often fail to capture the specific goals of the farmers and to understand the constraints under which they operate (Vanclay, 2003) and that adoption is driven by the relative advantage over current practice, risk reduction and the compatibility with existing farm practices (Pannell et al., 2006).

\section{Conclusions}

As an important food producer and the largest user of freshwater resources in South Africa, the irrigation industry has a vital role to play in achieving the country's water goal of 'Some, for all, forever'. WRC-funded research efforts over the past 4 decades to develop, improve and promote the use of irrigation-scheduling tools in South Africa have been impressive, but challenges remain and much work still needs to be done, especially to support the application of such tools.

No single method of irrigation scheduling has met with universal appeal. In most cases new developments have only taken root where long and consistent back-up was provided, either by the scientists involved themselves or by consultants. There is no simple way to measure water-use efficiency, but when the effort is made, the results invariably show that there is vast room for improvement. It is frustrating that uptake of novel technologies has been so slow.

This is not unique to South Africa, and begs the question of whether or not the approach by biophysicists has been somewhat naive? Irrigation is just one part of a profitable farm business, and researchers have perhaps often not always fully understood the constraints under which irrigators operate. Ultimately, together as water users, we will need to learn our way into the future and become better managers of water and the solutes it carries; this will involve a whole range of different technologies.

We propose 4 responses to these challenges worth pursuing. Firstly, continue to advance existing technology related to direct measurement of volumetric soil-water content coupled with advances in remote data access through radio communication or via cellular networks; secondly, new and emerging technology may yet overcome the barriers that have plagued existing technology; thirdly, approaches that make 'userfriendliness' the main focus should receive attention; and finally, we need to develop simple monitoring tools and engage irrigators in a process of adaptive learning by combining the best that different methods have to offer.

Given the urgency of the need to save water, and the sound understanding of the physical principles governing the functioning of the soil-plant-atmosphere system developed by science over the years, more determined effort is needed to bridge the gap between science and the application of this knowledge on farm. 


\section{Acknowledgements}

The authors would like to thank the WRC for continued support over many years, and for dragging us out of our technical 'comfort zones' and encouraging us to cross the chasm - from theory to practice.

\section{References}

ALLEN RG, PEREIRA LS, RAES D and SMITH M (1998) Crop evapotranspiration. FAO Irrigation and Drainage Paper 56. Food and Agriculture Organization (FAO), Rome, Italy. 300 pp.

ANNANDALE JG, BELETSE YG, DE JAGER PC, JOVANOVIC NZ, STEYN JM, BENADÉ N, LORENTZ SA, HODGSON FDI, USHER B, VERMEULEN D and AKEN ME (2007) Predicting the Environmental Impact and Sustainability of Irrigation with Coal Mine Water. WRC Report No. 1149/1/07, Water Research Commission, Pretoria, South Africa.175 pp.

ANNANDALE JG, BENADÉ N, JOVANOVIC NZ, STEYN JM and DU SAUTOY (1999a) Facilitating Irrigation Scheduling by Means of the Soil Water Balance Model. WRC Report No. 753/1/99, Water Research Commission, Pretoria, South Africa. 285 pp.

ANNANDALE JG, JOVANOVIC NZ, BENADÉ N and TANNER PD (1999b) Modelling the long-term effect of irrigation with gypsiferous water on soil and water resources. Agric. Ecosyst. Environ. 76 109-119.

ANNANDALE JG, CAMPBELL GS, OLIVIER FC and JOVANOVIC NZ (2000) Predicting crop water uptake under full and deficit irrigation. An example using pea (Pisum sativum cv. Puget). Irrig. Sci. 19 65-72.

ANNANDALE JG, JOVANOVIC NZ, MPANDELI NS and LOBIT P (2002a) Two Dimensional Energy Interception and Water Balance Model for Hedgerow Tree Crops. WRC Report No. 945/1/02 Water Research Commission, Pretoria, South Africa. 217 pp.

ANNANDALE JG, JOVANOVIC NZ, TANNER PD, BENADÉ N, DU PLESSIS HM (2002b) Sustainability of irrigation with gypsiferous mine water. Mine Water Environ. 21 81-90.

ANNANDALE JG, JOVANOVIC NZ, PRETORIUS JJB, LORENTZ SA, RETHMAN NFG and TANNER PD (2001) Gypsiferous mine water use in irrigation on rehabilitated open cast mine land: crop production, soil water and salt balance. Ecol. Eng. 17 153-164.

ANNANDALE JG and STOCKLE CO (1994) Fluctuation of crop evapotranspiration coefficients with weather: a sensitivity analysis. Irrig. Sci. 15 1-7.

ANNANDALE JG, STEYN JM, BENADÉ N, JOVANOVIC NZ and SOUNDY P (2005) Technology Transfer of the Soil Water Balance (SWB) Model as a User-Friendly Irrigation Scheduling Tool. WRC Report No. TT 251/05, Water Research Commission, Pretoria, South Africa. $80 \mathrm{pp}$.

ANNANDALE JG, VAN DER WESTHUIZEN AJ and OLIVIER FC (1996) Die Fasilitering van Tegnologie Oordrag deur Verbeterde Besproeiingsriglyne vir Groente en 'n Meganistiese Gewasmodeleringbenadering (Facilitating Technology Transfer Through Improved Irrigation Guidelines of Vegetables and a Mechanistic Crop Modelling Approach). WRC Report No. 476/1/96, Water Research Commission, Pretoria, South Africa. $179 \mathrm{pp}$.

ARC-ISCW (2005) Overview of the Agricultural Natural Resources of South Africa. ARC-ISCW Report No.GW/A/2004/13. (CD-ROM) ARC-Institute for Soil, Climate and Water, Pretoria, South Africa. $129 \mathrm{pp}$.

BASTIAANSSEN WGM, MOLDEN DJ and MAKIN IW (2000) Remote sensing for irrigated agriculture: examples from research and possible applications. Agric. Water Manage. 46 137-155.

BEMBRIDGE TJ (2000) Guidelines for Rehabilitation of Small-Scale Farmer Irrigation Schemes in South Africa. WRC Report No. 891/1/00, Water Research Commission, Pretoria, South Africa. $199 \mathrm{pp}$.

BENADÉ N, ANNANDALE JG, JOVANOVIC NZ, MEIRING JA and CROUS CR (2002) The Development of An Integrated Information System for Irrigation Water Management using the WAS SWB and
RiskMan Computer Models. WRC Report No. 946/4/02, Water Research Commission, Pretoria, South Africa. 282 pp.

BENNIE ATP (1995) Sound water management concepts and their application at farm level. Proc. Southern African Irrigation Symposium. 4-6 June 1991, Durban, South Africa. WRC Report No. TT 71/95 Water Research Commission, Pretoria, South Africa. pp. 287-294.

BENNIE ATP, COETZEE MJ, VAN ANTWERPEN R, VAN RENSBURG LD and BURGER RD (1988) Water Balance Model for Irrigation Based on Soil Profile Water Supply Rate. WRC Report No. 144/1/88. Water Research Commission, Pretoria, South Africa. 405 pp.

BENNIE ATP, STRYDOM MG and VERY HS (1998) Use of Computer Models for Agricultural Water Management on Ecotope Level. WRC Report No. TT 102/98. Water Research Commission, Pretoria, South Africa. $250 \mathrm{pp}$.

BENNIE ATP, VAN RENSBURG LD, STRYDOM MG and DU PREEZ CC (1997) Reaksie van Gewasse op Voorafgeprogrammeerde Tekortbesproeiing (Reaction of Crops to Pre-Programmed Deficit Irrigation). WRC Report No. 423/1/97. Water Research Commission, Pretoria, South Africa. 225 pp.

BENNIE ATP and HENSLEY M (2001) Maximizing precipitation in dryland agriculture in South Africa - a review. J. Hydrol. 241 124-139.

BEUKES O, VOLSCHENK T, DE VILLIERS JF and KARSTEN JHM (2003) Deficit Irrigation Studies to Improve Irrigation Scheduling in Deciduous Fruit Orchards. WRC Report No. 892/2/03. Water Research Commission, Pretoria, South Africa. 100 pp.

BOEDT LJJ and LAKER MC (1985) The Development of Profile Available Water Capacity Models. WRC Report No. 98/1/85. Water Research Commission, Pretoria, South Africa. 448 pp.

BOTHA CAJ, STEYN GJ and STEVENS JB (2000) Factors which Influence the Acceptability of Irrigation Scheduling with Specific Reference to Scheduling Models. WRC Report No. 893/1/00. Water Research Commission, Pretoria, South Africa. 199 pp.

BOTHA FJP, BENNIE ATP and BURGER RduT (1983) Water Use Efficiency of Irrigated Crops as Influenced by Varying Cultivation Practices and Root Configurations. Department of Soil Science, UOFS, Bloemfontein. 391 pp.

BUCHHEIM JF and PLOSS LF (1977) Computerized irrigation scheduling using neutron probes. Proc. 1977 Annual Conference of the American Society of Agricultural Engineers. ASAE, St. Joseph, Michigan, US.

BURGERS MS and KIRK RD (1993) Practical Scheduling of Irrigation in the Northern Transvaal. WRC Report No. 152/1/93. Water Research Commission, Pretoria, South Africa. 161 pp.

CAR N, CHRISTEN E, HORNBUCKLE J and MOORE G (2010) ET-based irrigation DSS using mobile phones where remote sensing is not applicable. Proc. Irrigation Australia Ltd Conference, 8-10 June 2010, Sydney, Australia,.

CHARLESWORTH PB (2005) Irrigation Insights No. 1 - Soil Water Monitoring ( $2^{\text {nd }}$ edition). National Program for Irrigation Research and Development, CSIRO Publishing, Melbourne, Australia.

COSTA JM, ORTUNO MF and CHAVES MM (2007) Deficit irrigation as a strategy to save water: Physiology and potential application to horticulture. J. Integrated Plant Biol. 49 1421-1434.

CROSBY C (2004) The GWK limited irrigation scheduling service. The Water Wheel May/June 2004. 14-17.

CROSBY CT and CROSBY CP (1999) SAPWAT: A Computer Program for Establishing Irrigation Requirements and Scheduling Strategies in South Africa. WRC Report No. 624/1/99. Water Research Commission, Pretoria, South Africa. 12 pp.

CROSBY CT, DE LANGE M, STIMIE CM, VAN DER STOEP I (2000) A Review of Planning and Design Procedures Applicable to Small-Scale Farmer Irrigation Projects. WRC Report No. 578/2/00. Water Research Commission, Pretoria, South Africa. $245 \mathrm{pp}$.

DE JAGER JM and KENNEDY JA (1996) Weather-Based Irrigation Scheduling for Various Farms (Commercial and Small-Scale). Water Reports 8: 33-38. Food and Agriculture Organization (FAO), Rome, Italy. 
DE JAGER JM and MOTTRAM R (1996) Saving water by scheduling irrigation using weather data. In: Sustainability of Irrigated Agriculture - the Future of Irrigation under Increased Demand from Competitive Uses of Water and Greater Needs for Food Supply (special session). Volume 1-E. Transactions $16^{\text {th }}$ International Congress on Irrigation and Drainage. Cairo, Egypt. 153-166.

DE JAGER JM, MOTTRAM R and KENNEDY JA (2001) Research on a computerised weather based irrigation water management system. WRC Report No. 581/1/01. Water Research Commission, Pretoria, South Africa. 180 pp.

DE JAGER JM and VAN ZYL WH (1989) Atmospheric evaporative demand and evaporation coefficient. Water SA 15 103-110.

DE JAGER JM and SINGELS A (1994) Research report by the Irrigation Planning Unit to the Department of Agriculture, Pretoria, South Africa. $6 \mathrm{pp}$.

DE JAGER JM, VAN ZYL WH, KELBE BE and SINGELS A (1987) Research on a weather service for scheduling the irrigation of winter wheat in the OFS. WRC Report No. 117/1/87. Water Research Commission, Pretoria, South Africa. 281 pp.

DENMEAD OT and SHAW RH (1962) Availability of soil water to plants as affected by soil moisture content and meteorological conditions. Agron. J. 54 385-90.

DOORENBOS J and PRUITT WO (1977) Guidelines for predicting crop water requirements. FAO Irrigation and Drainage Paper 33 Food and Agriculture Organization (FAO), Rome, Italy. 193 pp.

DWAF (DEPARTMENT OF WATER AFFAIRS AND FORESTRY, SOUTH AFRICA) (2004) National Water Resource Strategy. $\left(1^{\text {st }}\right.$ edn.). September 2004. Department of Water Affairs and Forestry, Pretoria, South Africa. $150 \mathrm{pp}$.

ENGLISH MJ and NAKAMURA BC (1982) Deficit irrigation: Effects of irrigation frequency on crop yield. Proc. Technical Conf. on Water, Energy and Economic Alternatives. The Irrigation Association, Falls Church, Virginia, US. 162-172.

FANADZO M, CHIDUZA C, MNKENI PNS, STOEP I and STEVENS J (2010) Crop production management practices as a cause for low water productivity at Zanyokwe Irrigation Scheme. Water SA 36 27-36.

FAO (2005) South Africa: Water and Food Security Country Profiles. URL: http://www.fao.org/nr/water/aquastat/countries/ south africa/south africa cp.pdf

FESSEHAZION, MK, STIRZAKER RJ, ANNANDALE JG, and EVERSON CS (2011) Improving nitrogen and irrigation water use efficiency through adaptive management: A case study using annual ryegrass. Agric. Ecosyst. Environ. 141 350-358.

FISCHER HH (1995) Scheduling of deficit irrigation for improved water use efficiency. Proc. Southern African Irrigation Symposium, 4-6 June 1991, Durban, South Africa. WRC Report No. TT 71/95 Water Research Commission, Pretoria, South Africa. pp. 344-349.

FISCHER HH and NEL PC (1990) Drupbespoeiing by Tamaties (Drip Irrigation in Tomatoes). WRC Report No. 185/1/90. Water Research Commission, Pretoria, South Africa. $181 \mathrm{pp}$.

GARDNER WR (1960) Dynamic aspects of water availability to plants. Soil Sci. 89 63-73.

GARDNER W and KIRKHAM D (1952) Determination of soil moisture by neutron scattering. Soil Sci. 73391.

GODFRAY HC, BEDDINGTON JR, CRUTE IR, HADDAD L, LAWRENCE D, MUIR JF, PRETTY J, ROBINSON S, THOMAS SM and TOULMIN C (2010) Food security: the challenge of feeding 9 million people. Science $\mathbf{3 2 7} 812-818$.

GRANT S (2000) Five-step irrigation schedule: Promoting fruit quality and vine health. Winegrowing May/June 2000, 1-4.

GREEN GC (1985) Estimated Irrigation Requirements of Crops in South Africa, Part 1. Memoirs on the Agricultural Resources of South Africa, No. 2. Department of Agriculture and Water Supply. Pretoria, South Africa.

HAARHOFF D (2011) Personal communication via e-mail on 21 October 2011. Manager: Research and Development, GriekwalandWes Koöperasie, Douglas, South Africa.

HENSLEY M and DE JAGER JM (1982) The Determination of the Profile Available Water Capacities of Soils. Department of Soil Science, University of Fort Hare, Alice, South Africa. 282 pp.
IDSO SB, JACKSON RD, PINTER PJ, REGINATO RJ and HATFIELD JL (1981) Normalizing the stress-degree-day parameter for environmental variability. Agric. Meteorol. 24 45-55.

JACKSON RD, IDSO SB, REGINATO RJ and PINTER PJ (1981) Canopy temperature as a crop water stress indicator. Water Resour. Res. 17 1133-1138.

JOVANOVIC NZ and ANNANDALE JG (1999) An FAO crop factor modification to SWB makes inclusion of crops with limited data possible: Examples for vegetable crops. Water SA 25 181-190.

JOVANOVIC NZ, ANNANDALE JG and MHLAULI NC (1999) Field water balance and SWB parameter determination of six winter vegetable species. Water SA 25 191-196.

JOVANOVIC NZ and ANNANDALE JG (2000a) Crop growth model parameters of 19 summer vegetable cultivars for use in mechanistic irrigation scheduling models. Water SA 26 67-76.

JOVANOVIC NZ and ANNANDALE JG (2000b) SWB (Soil Water Balance): A computer tool for teaching future irrigation managers. J. Nat. Resour. Life Sci. Educ. 29 15-22.

JOVANOVIC NZ, ANNANDALE JG, CLAASSENS AS, LORENTZ SA, TANNER PD, AKEN ME and HODGSON FDI (2002) Commercial production of crops irrigated with gypsiferous mine water. Water $S A \mathbf{2 8}$ 413-421.

JOVANOVIC NZ, ANNANDALE JG and HAMMES PS (2000a) Teaching crop physiology with the soil water balance (SWB) model. J. Nat. Resour. Life Sci. Educ. 29 23-30.

JOVANOVIC NZ, ANNANDALE JG and NEL AA (2000b) Calibration and validation of the SWB model for sunflower (Helianthus annuus L.). S. Afr. J. Plant Soil 17 117-123.

JUMMAN A (2009) A Framework to Improve Irrigation Design and Operating Strategies in the South African Sugarcane Industry. M.Sc. (Eng) Dissertation, University of KwaZulu-Natal, Pietermaritzburg, South Africa. $15 \mathrm{pp}$.

LAKER MC (1982) Appendix 8.1 A provisional simple model for predicting PAWC for certain Ciskeian soils. In: Hensley M and De Jager JM (ed.) The Determination of the Profile Available Water Capacities of Soils. Department of Soil Science, University of Fort Hare, Alice, South Africa. pp. 235-254

LAKER MC (1985) The utilization of heavier soils for irrigation and using the water storage capacities of soils to reduce design peaks. Proc. SABI Conf., Christiana, 14-17 March 1985, Christiana, South Africa. Available from mlaker@telkomsa.net.

LAKER MC, BOEDT LJJ and HENSLEY M (1987) Pre-dawn leaf water potential as indicator of plant water stress - with special reference to problems encountered under conditions of high evaporative demand. Proc. Int. Conf. on Measurement of Soil and Plant Water Status Vol. 2, 6-10 July 1987, Utah State Univ., Logan, US. pp. $25-29$.

LAKER MS (2004) The Effect of Atmospheric and Soil Conditions on the Grapevine Water Status. M.Sc. Agric. dissertation. University of Stellenbosch, Stellenbosch. 107 pp.

LATEGAN E and HOWELL CL (2010) The partial rootzone drying (PRD) of merlot in the Breede River Valley (Part 1): Irrigation volumes, plant water stress and vigour. Wynboer Technol. Yearbook 2010, pp. 19-21.

LEIB BG, HATTENDORF M, ELLIOT T and MATTHEWS G (2002) Adoption and adaption of scientific irrigation scheduling: trends from Washington, USA as of 1998. Agric. Water Manage. 55 105-120.

MARAIS D, RETHMAN NFG and ANNANDALE JG (2002) Water Use and Water Use Efficiency of Fodder Crops under Irrigation: Part 1 - Annual Subtropical Crops. WRC Report No. 573/1/02. Water Research Commission, Pretoria, South Africa. 76 pp.

MEYER WS, OOSTERHUIS DM, BERLINER PR, GREEN GC and VAN DER MERWE AJ (1987) Evapotranspiration and Water Use Studies in Wheat and Soybeans with the Help of the Weighing Lysimeter Technique. WRC Report No. H2/1/87. Water Research Commission, Pretoria, South Africa. 4 pp.

MILLER DE (1977) Deficit high frequency irrigation of sugarbeet, wheat and beans. Proc. Speciality Conf. on Water, Irrigation and Management for Drainage. ASCE, New York.

MKHIZE SS, VANASSCHE FMG and LAKER MC (1996) The Response of Citrus Seedlings to Soil Compaction and Variations in 
Soil Water Potential in the Upper Range of Plant Available Water. WRC Report No. 261/1/96. Water Research Commission, Pretoria, South Africa. $250 \mathrm{pp}$.

MONTEITH JL (1977) Climate and efficiency of crop production in Britain. Philos. Trans. R. Soc. London, Ser. B 281 277-294.

MOTTRAM R and DE JAGER JM (1994) Research on maximising irrigation project efficiency in different soil-climate-irrigation situations. WRC Report No. 226/1/94. Water Research Commission, Pretoria, South Africa.197 pp.

MYBURGH PA (2011a) Response of Vitis vinifera L. cv. Merlot to low frequency drip irrigation and partial root zone drying in the Western Cape coastal region. S. Afr. J. Enol. Vitic. 32 89-103.

MYBURGH PA (2011b) Personal communication via e-mail on 20 October 2011. Soil scientist, ARC-Infruitec/Nietvoorbij, Stellenbosch.

NEL AA (1995a) Irrigation timing using leaf water potential of wheat. Proc. Southern African Irrigation Symposium. 4-6 June 1991, Durban, South Africa. WRC Report No. TT 71/95. Water Research Commission, Pretoria, South Africa. pp. 336-340.

NEL FJ (1995b) Irrigation management on large farms, with special reference to the use of a neutron hydroprobe. Proc. Southern African Irrigation Symposium, 4-6 June 1991, Durban, South Africa. WRC Report No. TT 71/95. Water Research Commission, Pretoria, South Africa. 305-307.

NIEUWOUDT WL, BACKEBERG GR and DU PLESSIS HM (2004) The value of water in the South African economy: Some implications. Agrekon 43 162-182.

OLIVIER FC, LECLER NL and SINGELS A (2009) Increasing Water Use Efficiency of Irrigated Sugarcane by Means of Specific Agronomic Practices. WRC Report No. 1577/1/09. Water Research Commission, Pretoria, South Africa. 127 pp.

PANNELL DJ, MARSHAL GR, BARR N, CURTIS A, VANCLAY F and WILKINSON R (2006) Understanding and promoting adoption of conservation practices by rural landholders. Aust. J. Exp. Agric. 46 1407-1424.

PASSIOURA JB (1988) Water transport in and to roots. Ann. Rev. Plant Phys. 39 245-265.

PAVEL EW and DE VILLIERS AJ (2004) Responses of mango trees to reduced irrigation regimes. Acta Hortic. 646 63-68.

PAVEL EW, VANASSCHE FMG and GROSSMAN YL (2003) Optimisation of Irrigation Management in Mango Trees by Determination of Water and Carbon Demands to Improve Water Use Efficiency and Fruit Quality. WRC Report No. 1136/1/03. Water Research Commission, Pretoria, South Africa. 87 pp.

POSTHUMUS C (2011) The intelligent pixel - helping the farmer. SABI Magazine April/May 2011, pp 10-11.

RATLIFF LF, RITCHIE JT and CASSEL DK (1983) Field measured limits of soil water availability as related to laboratory-measured properties. Soil Sci. Soc. Am. J. 47 770-775.

REGINATO RJ (1995) Crop water stress assessment for irrigation management. Proc. Southern African Irrigation Symposium. 4-6 June 1991, Durban, South Africa. WRC Report No. TT 71/95. Water Research Commission, Pretoria, South Africa. pp. 284-286.

REINDERS FB, VAN DER STOEP I, LECLER NL, GREAVES KR, VAHRMEIJER JT, BENADÉ N, DU PLESSIS FJ, VAN HEERDEN PS, STEYN JM, GROVÉ B, JUMMAN A and ASCOUGH G (2010) Standards and Guidelines for Improved Efficiency of Irrigation Water Use from Dam Wall Release to Root Zone Application: Guidelines. WRC Report No. TT 466/10. Water Research Commission, Pretoria, South Africa. 234 pp.

RICHARDS LA and NEAL OR (1936) Some field observations with tensiometers. Soil Sci. Soc. Am. Proc. 171.

ROBBINS CH (1991) Solute transport and reactions in salt-affected soils. In: Hanks RJ and Ritchie JT (eds.) Modelling Plant and Soil Systems. Agron. Mono. No. 31. ASA-CSSA-SSSA, Madison, WI. 365-395.

SANTOS C, LORITE IJ, TASUMI M, ALLEN RG and FERERES E (2008) Integrating satellite-based evapotranspiration with simulation models for irrigation management at the scheme level. Irrig. Sci. 26 277-288.

SAVAGE MJ and WIEBE HH (1987) Effect of conductance on water vapor pressure determination of leaf water potential. Proc. Int.
Conf. on Measurement of Soil and Plant Water Status Vol. 2. 6-10 July 1987, Utah State Univ., Logan, US. 55-61.

SAVAGE MJ, GRAHAM and LIGHTBODY KE (2000) An Investigation of the Stem Steady State Heat Energy Balance Technique in Determining Water Use by Trees. WRC Report No. 348/1/00. Water Research Commission, Pretoria, South Africa. 181 pp.

SINGELS A (2007) A new approach to implementing computer-based decision support for sugarcane farmers and extension staff. The case of My Canesim. Proc. Int. Soc. Sugar Cane Technol. 26 211-219 (also published in Sugar Cane Int. 26 22-25).

SINGELS A and SMITH MT (2006) Provision of irrigation scheduling advice to small-scale sugarcane farmers using a web based crop model and cellular technology: A South African case study. Irrig. Drain. 55 363-372.

SINGELS A and SMITH MT (2009) Real Time Irrigation Advice for Small-Scale Sugarcane Production Using A Crop Model. WRC Report No. K5/1576/4. Water Research Commission, Pretoria, South Africa. $147 \mathrm{pp}$.

SMITH M, ALLEN RG and PEREIRA LS (1996) Revised FAO methodology for crop water requirements. Proc. of the Int. Conf. on Evapotranspiration and Irrigation Scheduling, San Antonio, Texas, USA. 133-140.

SPREER W, NAGLE M, NEIDHART S, CARLE R, ONGPRASERT $S$ and MÜLLER J (2007) Effect of regulated deficit irrigation and partial rootzone drying on the quality of mango fruits (Mangifera indica L., cv. 'Chock Anan'). Agric. Water Manage. 88 173-180.

STEVENS JB, DUVEL GH, STEYN GJ and MAROBANE W (2005) The Range, Distribution and Implementation of Irrigation Scheduling Models and Methods in South Africa. WRC Report No. 1137/1/05. Water Research Commission, Pretoria, South Africa. $208 \mathrm{pp}$.

STEVENS JB and STIRZAKER RJ (2010) Wetting Front Detector Transfer of Technology. WRC Report No. K8/599/4. Water Research Commission, Pretoria, South Africa. 30 pp.

STEYNBERG RE, NEL PC and RETHMAN NFG (1994) Waterverbruik en Waterverbruiksdoeltreffendheid van Gematigde Aanplante Weidings onder Bespoeiing (Water Use and Water Use Efficiency of Temperate Planted Pastures under Irrigation). WRC Report No. 257/1/94. Water Research Commission, Pretoria, South Africa.

STIRZAKER RJ (1999) The problem of irrigated horticulture: matching the biophysical efficiency with the economic efficiency. Agrofor. Syst. 45 187-202.

STIRZAKER RJ (2003) When to turn the water off: scheduling microirrigation with a wetting front detector. Irrig. Sci. 22 177-185.

STIRZAKER RJ (2006) Soil Water Monitoring. State of Play and Barriers to Adoption, Irrigation Matters Series 01/06. CRC for Irrigation Futures. Darling Heights, Qld. URL: www.irrigationfutures.org.au/news.asp?catID $=12 \& I D=440$

STIRZAKER RJ (2008) Factors affecting sensitivity of wetting front detectors. In: Goodwin I and O'Connell MG (eds.) Proc. $5^{\text {th }}$ International Symposium on Irrigation of Horticultural Crops. Acta Hort. 792 647-654.

STIRZAKER RJ (2011) Strategy, tactics and heuristics for managing solutes in horticultural crops. Acta Hort. 889 59-65.

STIRZAKER RJ and HUTCHINSON PA (2005) Irrigation controlled by a wetting front detector: field evaluation under sprinkler irrigation. Aust. J. Soil Res. 43 935-943.

STIRZAKER R, STEVENS J, ANNANDALE J, MAEKO T, STEYN J, MPANDELI S, MAUROBANE W, NKGAPELE J and JOVANOVIC N (2004) Building Capacity in Irrigation Management with Wetting Front Detectors. WRC Report No. TT 230/04. Water Research Commission, Pretoria, South Africa. 85 pp.

STIRZAKER RJ, STEVENS JB, ANNANDALE JG and STEYN JM (2010a) Stages in the adoption of a wetting front detector. Irrig. Drain. $59367-376$

STIRZAKER RJ, STEYN JM, ANNANDALE JG, ADHANOM G, VAN DER LAAN M and M'MARETE C (2010b) Adapting the Wetting Front Detector to Small-Scale Furrow Irrigators and Providing a Basis for the Interpretation of Salt and Nutrient Measurements from the Water Sample. WRC Report No. 1574/1/10. Water Research Commission, Pretoria, South Africa. 99 pp. 
STREUTKER A (1978) Tensiometer controlled medium frequency topsoil irrigation: a technique to improve agricultural water management. Water SA 4 134-155.

STREUTKER A, MOLENAAR HW, HAMMAN H, NEL CC and MULDER JH (1981) Besproeiing, Gewasopbrengs en Dreinering op die Vaalhartsbesproeiingskema: 2. Die Voorkoms van Verbrakte Grond en die Invloed van Dreinering Daarop (Irrigation, Crop Yield and Drainage at the Vaalharts Irrigation Scheme: 2. The Occurrence of Salt-Affected Soils and the Effect of Drainage on It). Water SA 7 175-184.

STRYDOM MG (1998) Kwantifisering van Insetparameters vir die Besproeiingskeduleringsprogram BEWAB vir Aartappels en Erte. M.Sc. (Agric) Dissertation, University of the Free State, Bloemfontein, South Africa. 207 pp.

TANNER CB and SINCLAIR TR (1983) Efficient water use in crop production: research or re-search? In: Taylor HM, Jordan WR and Sinclair TR (eds.) Limitations to Efficient Water Use in Crop Production. American Society of Agronomy, Crop Science Society of America, and Soil Science Society of America, Madison, Wisconsin. pp 1-27.

TESFAMARIAM EH (2004) Modelling the Soil Water Balance of Canola Brassica napus L (Hyola 60). M.Sc. (Agric) Dissertation. University of Pretoria, South Africa. $120 \mathrm{pp}$.

TESFAMARIAM EH (2009) Sustainable Use of Sewage Sludge as a Source of Nitrogen and Phosphorus in Cropping Systems. Ph.D. Dissertation, University of Pretoria, South Africa. 270 pp.

VANASSCHE FMG and LAKER MC (1989) Research on Improving Irrigation Management Based on Soil Water Monitoring and Detailed Knowledge of Profile Available Water Capacities. WRC Report No. 166/1/89. Water Research Commission, Pretoria, South Africa. 347 pp.

VAN AVERBEKE W and NETSHITHUTHUNI C (2010) Effect of irrigation scheduling on leaf yield of non-heading Chinese cabbage (Brassica rapa L. subsp. chinensis). S. Afr. J. Plant Soil 27 322-326.

VANCLAY F (2003) Social principles to inform agriculture. In: Wilson BP and Curtis A (eds.) Agriculture for the Australian Environment. Proc. 2002 Australian Academy of Science Fenner Conference on the Environment. Charles Sturt University, Australia. 9-24.
VAN DER LAAN M (2009) Development, Testing and Application of a Crop Nitrogen and Phosphorus Model to Investigate Leaching Losses at the Local Scale. Ph.D. Dissertation, University of Pretoria, South Africa. $178 \mathrm{pp}$.

VAN DER LAAN M, STIRZAKER RJ, ANNANDALE JG, BRISTOW KL and DU PREEZ CC (2010) Monitoring and modelling draining and resident soil water nitrate concentrations to estimate leaching losses. Agric. Water Manage. 97 1779-1786.

VAN VUUREN L (2011) Improved water use only a satellite away. The Water Wheel, September/October 2011. 14-17.

VAN ZYL WH and DE JAGER JM (1992) Effect of climate on plant evaporation coefficients for the potato crop. Agric. For. Meteorol. 60 167-179.

VAN ZYL WH and DE JAGER JM (1994) Research on the Climatic Dependence of Evaporation Coefficients. WRC Report No. 260/1/94. Water Research Commission, Pretoria, South Africa. $166 \mathrm{pp}$.

VAN ZYL WH, DE JAGER JM and MAREE CJ (1989) The relationship between daylight evaporation from short vegetation and the USWB Class A pan. Agric. For. Meteorol. 46 107-118.

VAN ZYL WH, DE JAGER JM, MAREE CJ and SINGELS A (1990) Canopy surface conductance of unstressed wheat and its weather dependence. Water SA 16 99-104.

VAN ZYL WH and DE JAGER JM (1987) Accuracy of the PenmanMonteith equation adjusted for atmospheric stability. Agric. For. Meteorol. 41 57-64.

VAN ZYL WH and DE JAGER JM (1992) Effect of climate on plant evaporation coefficients for the potato crop. Agric. For. Meteorol. 60 167-179.

VOLSCHENK T, DE VILLIERS JF and BEUKES O (2003) The Selection and Calibration of a Model for Irrigation Scheduling of Deciduous Fruit Orchards. WRC Report No. 892/1/03. Water Research Commission, Pretoria, South Africa. 126 pp.

WALKER S (2000) Irrigation Requirements of Selected Crops under Small-Scale Production: Linking On-Farm and On-Station Research. WRC Report No. 689/1/00. Water Research Commission, Pretoria, South Africa. 146 pp.

WATER RESEARCH COMMISSION (1995) Proceedings of the Southern African Irrigation Symposium, 4-6 June 1991, Durban, South Africa. WRC Report No. TT 71/95. Water Research Commission, Pretoria, South Africa. 435 pp. 
http://dx.doi.org/10.4314/wsa.v37i5.12 Available on website http://www.wrc.org.za

ISSN 0378-4738 (Print) = Water SA Vol. 37 No. 5 WRC 40-Year Celebration Special Edition 2011 ISSN 1816-7950 (On-line) = Water SA Vol. 37 No. 5 WRC 40-Year Celebration Special Edition 2011 